\title{
Colonization of Staphylococcus xylosus in the kidneys and bladder of mice
}

\author{
Harith J. F. Al-Mathkhury*
}

Date of acceptance 7/11/2007

\begin{abstract}
Two isolates of Staphylococcus xylosus (urease producer and non urease producer) were injected in mice at a dose of $2 \times 10^{8}$ colony-forming units (CFU) intraurethrally. Results showed that both isolates were able to colonize kidney and bladder of the injected mice, regardless of their urease production. Moreover, there were insignificant differences between the two groups. These results emphasized the pathogenicity of this bacteria in UTI.
\end{abstract}

\section{Introduction}

Coagulase-negative staphylococci (CoNS) are common inhabitants of the skin, skin glands and mucous membranes of various mammals and birds $(1,2)$. Although these organisms are part of the normal flora and are generally considered to be of low virulence, they appeared to be implicated in the aetiology of a variety of human and animal infections, and they have established themselves as important pathogens showing increasing trends towards antibiotic resistance in the last decade (3).

Staphylococcus xylosus is a gram positive, coagulase negative, novobiocin resistant and xylose fermenter (4). Some strains of $S$. xylosus are opportunistic pathogens have been isolated from nosocomial infections, have been described as multi-resistant to diverse antibiotics (5).

These organisms may contribute to development and stabilization of color, inhibition of rancidity, and improvement of the flavor of cured ham by reductases, catalases, and lipases (6)

It was mentioned that this bacteria is the causing agent of urinary tract infections (UTI) in women (7), cutaneous lesion when it injected in mice (8). This bacterium has several virulence factors like hemolysin (9), urease (10), proteases (11), and lipase (12).

Unlike Staphylococcus epidermidis and S. saprophyticus, less attention was paid toward S. xylosus as causing agent of UTI since its percentage was around $1 \%$ $(13,14,15)$. However, recently, it was isolated with high percentage $(25 \%)$ (16) and $16.3 \%$ (17) from UTI patients, hence the purpose of this study was to investigate the colonization of $S$. xylosus as causative agent of UTI in kidney and urinary bladder.

\section{Material and Methods Microorganism}

Two isolates of $S$. xylosus (one is urease positive and the other one is urease negative) were isolated from UTI patients on mannitol salt agar (Himedia), both are susceptible to ciprofloxacin and resistant to erythromycin, gentamicin and amoxicillin. They were cultured in Brain heart infusion (Himedia) at $37^{\circ} \mathrm{C}$ for $24 \mathrm{~h}$. then cultures were collected by centrifugation at $6,000 \times \mathrm{g}$ for $10 \mathrm{~min}$ and resuspended in phosphate-buffered saline (PBS).

\section{Animals}

Nine female mice (Mus musculus), aged 8 weeks, weighing $25-30$ gm were

*Department of Biology, College of Science, University of Baghdad 
divided into three groups. Group one and two were challenged with $2 \times 10^{8}$ colony-forming units (CFU)/ml of urease producing and non urease producing $S$. xylosus, respectively, suspended in phosphate buffer saline (PBS), while the third group was injected with (PBS) which referred to as control group, using an ascending UTI model as described below.

\section{Inoculation protocol}

The inoculation was performed by introducing the bacterial suspension or PBS transurethrally, After sterilization of the periurethral area with $70 \%$ ethanol a soft polyethylene catheter (outer diameter $0.6 \mathrm{~mm}$ ) was inserted through the urethra and $0.2 \mathrm{ml}$ of the bacterial suspension or PBS was slowly introduced into the bladder over a period of not less than $30 \mathrm{~s}$ to avoid vesicourethral reflux (18). Four days after challenge, mice were euthanised by cervical dislocation. Bladders and kidneys were removed aseptically and separately homogenised in $10 \mathrm{ml}$ of PBS using a Lab Blender. Homogenised tissues were quantitatively cultured on nutrient agar. The number of CFU per bladder or kidney was determined after $24 \mathrm{~h}$ of incubation at $37^{\circ} \mathrm{C}(19)$.

\section{Bacteriological analysis}

To determine the number of viable bacteria in organs, $50-\mu 1$ portions were spread onto the nutrient agar (Difco). The plates were incubated aerobically at $37^{\circ} \mathrm{C}$ for $24 \mathrm{~h}$. Results are expressed as the mean number of bacteria (CFU) in the entire organ (20).

\section{Statistical analysis}

Statistical differences between the control group and the treated group were evaluated with Student's $t$ test for. A $P$ value of $<0.05$ was considered significant.

\section{Results and Discussion}

S. xylosus was able to colonize both kidney and bladder of the injected mice regardless of their urease production. Moreover, there were insignificant differences between group one and two, while there were significant differences between bacterial counts in kidney and bladder as the former was higher than the latter (table 1).

Table 1: Bacterial counts (CFU) in mice renal system challenged with $2 \times 10^{8}$ CFU/ml of S. xylosus*

\begin{tabular}{|l|c|c|}
\hline Organ & $\begin{array}{c}\text { S. xylosus urease } \\
\text { positive }\end{array}$ & $\begin{array}{c}\text { S. xylosus urease } \\
\text { negative }\end{array}$ \\
\hline $\begin{array}{c}\text { Urinary } \\
\text { bladder }\end{array}$ & $5.6 \times 10^{3}$ & $5.2 \times 10^{3}$ \\
\hline Kidney & $4.8 \times 10^{4}$ & $5 \times 10^{4}$ \\
\hline
\end{tabular}

${ }^{*}$ Each datum is a mean of triplicate

As it can be seen from table (1) bacterial counts in kidney is more than in bladder and that could be due to clearance of non adherent bacteria from the bladder by mechanical forces of urine flow and other innate defenses. The higher counts of S. xylosus in the kidneys indicated that the bacteria in the kidney were able to establish residence capable of evading innate defenses. Nevertheless, this assumption is needed to be investigated intensively.

The present study results have an agreement with the study of Kau and his coworkers as they used a mouse model of urinary tract infection, they have shown that Eenterococcus faecalis is capable of persisting in the kidneys of mice for at least 2 weeks. In contrast, bacterial titers from the bladders of the same mice were inconsistent and tended to be much lower than those recovered from the kidney. This preference for the kidney over the bladder is also observed in other clinical $E$. faecalis strains (21). 
These results agreed with Al-Ghrairy (17) as he mentioned that $S$. xylosus caused several histopathological changes in mice kidney and bladder. Furthermore, the urease producer caused damage more than non urease producer. According to the present results this damage could be attributable to urease production or to another virulence factors rather than to bacterial colonization density inside the organ.

Scavone and his coworkers (19) mentioned that challenging mice with $2 \times$ $10^{8}$ colony-forming units (CFU) of Proteus mirabilis Pr2921, resulted in harboring the kidney with $6.3 \times 10^{6}$ while urinary bladder showed $5 \times 10^{5}$.

Asahara et al found that Escherichiacoli strain HU-1 at an inoculum size of $2 \times 10^{6} \mathrm{CFU}$ into the bladder induced a local transitory infection in the mice, as the bladder harbored $3 \times 10^{6}$ $\mathrm{CFU}$ and kidneys harbored $10^{4} \mathrm{CFU}$. However, the number of polymorphonuclear leukocytes and myeloperoxidase activity in the urine were markedly elevated during the infection period (20).

Regarding the study of Al-heety (16) and Al-Ghrairy (17) which isolated $S$. xylosus with high percentages and considering the studies of Scavone and his coworkers (19) and Asahara et al. (20) it can be suggested that the $S$. xylosus is considered as an important UTI pathogen since it has the ability to colonize the urinary system and cause severe damage.

\section{References}

1. Nagase, N., Sasaki, A., Yamashita, K., Shimizu, A., Wakita, Y., Kitai, S. \& Kawano, J. 2001. Isolation and species distribution of staphylococci from animal and human skin. J. Vet. Med. Sci. 64, 245-250.

2. Hauschild, T. 2001. Phenotypic and genotypic identification of staphylococci isolated from wild small mammals. Syst Appl Microbiol 24: 411-416.

3. von Eiff, C., Proctor, R. A. \& Peters, G. 2001. Coagulase-negative staphylococci. Pathogens have major role in nosocomial infections. Postgrad Med 110: 63-76.

4. Holt, J. G.; Krieg, N. R.; Sneath, P. H. A.; Staley, J. T. and Williams, S. T. 1994. Bergy's Manual of Determinative Bacteriology. 9th ed. Williams and Wilkins. Maryland, USA.

5. Barreire, C., Bruncker, R. and Talon, R. 2001. Characterization of single superoxide dismuatse of Staphylococcus xylosus. J.Appl.Environ.Microbiol. 67: 4096-4104.

6. Rodri'guez, M., Ez, F., Co'rdoba, J., Dez. E, and Asensio, M. 1996. GramPositive, Catalase-Positive Cocci from Dry Cured Iberian Ham and Their Enterotoxigenic Potential. Appl. Environ. Microbiol. 62:1897-1902.

7. Rupp, M. E.; Soper, D. E. and Archer, G. L. 1992. Colonization of the female genital tract with Staphylococcus saprophyticus. J. Clin. Microbiol. 30 (11): 2975-2979.

8. Thornton, V., Dovis, J., Clair, S., and Cole, M. 2003. Inoculation of Staphylococcus xylosus in JL/J mice to determine pathogenicity. Anim.Sci. 212: 49-52.

9. Sawicka -Grezelak, A., Szymanowska, A., Mlynarczyk, A. and Mlynarczyk, G. 1993. Production of staphylolysin and hemolysin by coagulase negative staphylococci. Med. Bosw.Microbiol. 45: 7-10.

10. Jose, J., Christians, S., Rosenstein. R., Gotz, F., and Kultwasser, H. 1991. Clonning and expression of various staphylococcal genes in coding urease in Staphylococcus carnosus . FEMS Microbial. Lett. 64: 277-281.

11. Casaburi, A., Villani, F., Toldra, F., and Sanz, Y. 2006. Protease and esterase activity of staphylococci. Int.J.Food Microbiol. 16: 216-219. 
12. Mosbah, H., Sayari, A., Bezzine, S., and Garguairy, D. 2006. Expression, purification and characterization of His tagged Staphylococcus xylosus lipase wild type and its mutant Asp 290 Ala. Protein exprpuf.J.Clin. 3: 189-195.

13. Tselenis-Kotsowilis, Koliomichalis, M.and Papvassiliou, J. 1982. Acute pyelonephritis caused by Staphylococcus xylosus.

$\mathrm{J}$. Clin.Micorbiol. 16:593-

14. Medscape .2004. Staphylococcus endocarditis. Infec.Med. 21: 68-72.

15. Novacova, D., Stetina, V., Ivosedleck, A., and Petras, P. 2005. Characterization of presumptive Staphylococcus xylosus strain by SDSPRGe protein profiles. J.Clin.Microbiol. 24: 176-179.

16. Al-heety, A. 2005. Role of peptidoglycan in pathogenicity of $S$. saprophyticus. MSc. Thesis. University of Baghdad, College of Science,Baghdad, Iraq.

17. Al-Ghrairy, Z. 2007. A comparative study on some pathological aspects between Staphylococcus xylosus and Staphylococcus saprophyticus. MSc.
Thesis. University of Baghdad, College of Science,Baghdad, Iraq.

18. Kaijser, B., Larsson, P., Olling, S. 1978. Protection against ascending Escherichia coli pyelonephritis in rats and significance of local immunity, Infect. Immun. 20: 78-81.

19. Scavone, P., Sosa, V., Pellegrino, R., Galvalisi, U., Zunino, P., 2004. Mucosal vaccination of mice with recombinant Proteus mirabilis structural fimbrial proteins. Microb. Infect. 6: 853-860.

20. Asahara, T., Nomoto, K., Watanuki, M., and Yokokura, T. 2001. Antimicrobial Activity of Intraurethrally Administered Probiotic Lactobacillus casei in a Murine Model of Escherichia coli Urinary Tract Infection. Antimicrob. Agents Chemother. 45: 1751-1760.

21. Kau, A., Martin, S., Lyon, W., Hayes, E., Caparon, M., and Hultgren, S. 2005. Enterococcus faecalis Tropism for the Kidneys in the Urinary Tract of C57BL/6J Mice. Infect. Immun. 73: 2461-2468.

\section{استيطانStaphylococcus xylosus الكلى و المثانة في الفئران}

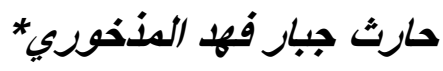

\footnotetext{
*قم علوم الحياة ، كلية العلوم ، جامعة بغداد

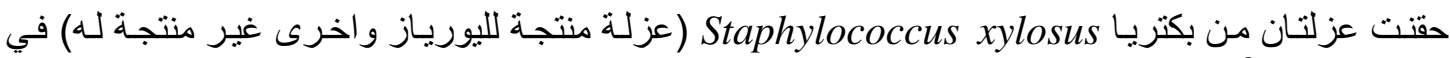

الفئران بجر عة مقدارها $10^{8}$ × 2 وحدة مكونة للمستعمرة عبر الاحليل. بينت النتائج ان كلا العزلتين التين تمكنتا من استيطان

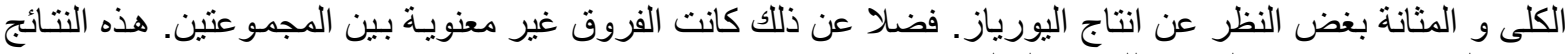

تؤكد على امر اضية هذه البكتريا للجهاز البولي.
} 